Article

\title{
Rhetorica and Exemplum: The Genesis of Christian Literature in Late Imperial China
}

\author{
Sher-Shiueh Li \\ Institute of Chinese Literature and Philosophy, Academia Sinica, Taipei 11529, Taiwan; \\ shiueh@gate.sinica.edu.tw
}

Received: 7 June 2019; Accepted: 1 August 2019; Published: 5 August 2019

Abstract: This paper offers a survey of how European rhetoric reached China in the transitional period between the Ming and the Qing dynasties. The focus of my paper is how a verbal ars is transformed into the written ars, thus inaugurating the Christian literature in late imperial China.

Keywords: rhetoric Jesuits Sino-Western literary relations; comparative literature; translation history in China

\section{Why Did the Ming Chinese Forget Rhetoric?}

Most students of late Ming and early Qing Jesuit writings (1583-1805) have reached the somewhat dubious conclusion that the Chinese converted to Catholicism because they were tempted by the excellence of European science and technology (Gernet 1986, pp. 15-24; Fan 1992; Chu 1996, pp. 47-97; Liu 2018; Han 2019). ${ }^{1}$ This traditional view, however, has been interrogated intensively ever since some twenty years ago (e.g., Zürcher 1996, pp. 331-60). One reason to doubt the standard interpretation is that conversion is commonly, though also with exceptions, the result of chuanhua 勸化or "persuasion," the ultimate purpose of rhetoric according to Aristotle (Kennedy 1991, 1.2.1). If the missionary works concerned have to rely greatly on writing, the act of persuasion may in fact have been more strategic and therefore rhetorical in nature. Its literariness, in fact, almost equals its religiosity if one agrees that rhetoricity is part of this quality. As scholars such as Billings (2009) and Redaelli (2007) have done, my investigation of the Ming and Qing Jesuit writings in Chinese finds that they, indeed, are comprised of a large amount of material that can be properly qualified as literary, including dialogues, hagiography, and collections of maxims, fables, and anecdotes.

Among these Jesuit works of seemingly apologetical nature, a special genre stands out: exemplum. An exemplum has been defined as a short narration given as truthful and intended to be inserted into a speech, usually a sermon, to convince an audience by means of a salutary lesson (Gregg 1997, pp. 11-16). To the best of my knowledge, works under this generic rubric have attracted few critical attentions in literary history, even though they contributed greatly to the masterpieces of such well-known authors in the West as Geoffrey Chaucer (1343-1400) and John Gower (c. 1330-1408). Exemplum is also a critical rhetorical device in the catechetic works of such important Ming Jesuits as Matteo Ricci (利瑪璸， 1552-1610) and Diego de Pantoja (龐迪我, 1571-1618). When it comes to rhetoric, let me begin with a short story about Ricci, the most important and famous figure in the first generation of Jesuits in China.

Before Ricci died in 1610, he had been harshly attacked once by Zou Weilian 㱀維璉 (d. 1636), one of the activists of the Dongling Party renowned in the political society of late-Ming China. Zou

1 For discussions in Western languages, see the titles listed in Zürcher 1991, pp. 101-24, or its expanded version by Nicolas Standaert, in Standaert 2001, pp. 238-45, and 936-41. On mathematics, there is one book worthy of our special mention: Engelfriet 1998. But studies on humanities also began long ago. For discussions particularly on literary works, see selected titles in Li and Lam 2014. 
criticized Ricci by saying that "as to that monster Li (Ricci), his tongue is as fast as the lightning, and his oration is as powerful as the waves. He is truly a Zhang Yi or a Su Qin in our times" (若乎利妖, 電光之舌, 波濤之辯, 真一儀秦; Zou 2001, 3:198a). ${ }^{2}$ Zhang and Su were two orators in the period known as Warring States of the Zhou Dynasty, also two figures about whom Zou Weilian knew quite well. The same remarks as Zou's made at the turn of the sixteenth century on Ricci's eloquence can be found in, for one more instance, Xie Zaozhe's 謝肇淛 (1567-1624) Wu zazhu 五雜㸖 (Xie 1959, juan 4, 1:120), regardless of those of other literati contemporizes of Ricci's. But Zou and Xie might not be aware that Ricci's eloquence, famed during the life span of his stay in China, was the result of his familiarity with European "rhetoric," the kind of verbal art that, to the best of my knowledge about China, had long been forgotten ever since Confucianism became dominant in the Hang Dynasty. ${ }^{3}$ With the exception of Liu Xie's 劉妿思 (c. 465-521) The Literary Mind and the Carving of the Dragon (文心雕龍), nearly no theoretical work on verbal art ever appeared before the modern era. Ricci, as were most of other Jesuits who came to China during the transitional period between the Ming and the Qing dynasty, was well trained in this particular art of effective speaking.

The reasons why the Chinese "forgot" their interest in rhetorical discourse, in my humble view, can be divided into several ones: First of all, the Confucian rejection of beautiful but not kind speech in the Analects, such as “one's cunning words and fawningly expression" (巧言令色) going in full support of the idea that this kind of person must have his "benevolence remain with only a small part" (鮮矣 仁; Zhu 1997, p. 62). Other accounts for the Ming ignorance of public speaking include what is more institutional than individualistic: beginning with town examination and ending with capital or palace ones, none of the different levels of the imperial examination required oral presentations. Whereas I do not know in what language Zou Weilian talked with Ricci, that which lies at the bottom of the above "ignorance" in traditional Chinese society is the lack of a sort of "common language" or "lingua franca," with which people from all regions of the empire were allowed to communicate without oral interpretation. The worst is, as Joseph Edkins (艾約瑟, 1823-1905), a Protestant missionary who spared no effort to promote rhetoric and Cicero in the late-Qing dynasty, pointed out at that time that in later times there were no such institutions as assemblies and councils (yihui 議會) in China that could continue the ancient legacy of rhetoric (Ai 2006, p. 523). George A. Kennedy keenly observes in his Comparative Rhetoric that, in sharp contrast to Western rhetoricians, Chinese rhetors, called pejoratively as chushi 處士 or zhonghen jia 縱橫家, if not cunningly, then surely were reactionary (Kennedy 1998, p. 143).

\section{European Jesuits and the Appearance of Western Rhetoric in China}

This notwithstanding, what concerns me in recollecting Ricci's story with reference to Zou Weilian, especially, is a question rarely raised by modern specialists in the field of Jesuit writings: To what degree was European rhetoric introduced by early Catholic missionaries in China? It is self-evident that Ricci's Western Mnemonics or Xiguo jifa 西國記法 is itself the outcome of his reworking on medieval rhetoric. ${ }^{4}$ Whereas the idea of rhetoric in Xiguo jifa is most likely Ciceronian, it does not mean that the Ming Jesuits knew this particular typology of rhetoric only. In his Xixue fan 西學凡 (1623) or the General Introduction to Western Learning, Julius Aleni (艾儒略, 1582-1649) has highlighted the three types of Aristotelian rhetoric by paraphrase: Deliberative speaking is employed "in times when the gentry cannot make a decision about things important, or to persuade people to shun from bad things or evil ways of life (衿紳偶有大事難決者, 或民習於还業, 沉於邪俗者).” Epideictic oratory is employed “in

2 For a biography of Zou Weilian, see Chen 1991, comp., juan 18, in Zhou 1991, 6:231. For Su and Zhang, see the discussion of them in Xing 1998, p. 87.

3 Not until the Song and the Ming, those Neo-Confucians, for teaching purposes, began to deliver longer speeches as we understand them today, although they were still not the outputs of an art equaled to the Greco-Roman art of speech. See Song and Huang 1991, pp. 166-259.

4 For the text of Xiguo jifa, please refer to Wu 1964,1-70. For a recent study on Xiguo jifa, see Ahn 2017, “On Xiguo jifa (『西國 記法』) of Matteo Ricci (1552-1610)," pp. 99-121. 
times when one is to talk about the merits of the virtuous or to criticize those whose behavior is vicious (或當誦説聖賢之功德, 或當譏彈不肖之惡行)." Forensic speaking is employed “to demand redress for a grievance, to make the cunning submitted, and to punish the mischievously sinned (枉者伸, 詐者 服，凶頑者罪; Ai 1964, p. 30)."

Another connection between the Ming Jesuits and Classical rhetoric lies in their meticulously clever use of exemplum, a specific genre that, as suggested above, comes from Aristotelian theory of pisteis. Most of the exempla, pursuant to Aristotle's Rhetoric, are "embodied in art" (2.2.1-2.2.3). One of the earliest Jesuit exempla concerns St. Augustine of Hippo (354-430), and appears in Michele Ruggieri's (羅明堅, 1543-1607) Tianzhu shengjiao shilu天主聖教實錄 (1584), which can be taken here for an exemple:

\section{...... [嘗] 聞古有一賢士, 欲盡明天主之説, 書夜尋思。一日在於海邊往來, 遇一童子, 手 執漏碗, 望海而行。士問曰：『子將何往？』童子曰：『吾執此碗, 欲汲盡此海水。』士笑 日：『欲以漏碗而汲盡滄海, 子言謬矣。』童子日：『爾既知漏碗不能汲竭海水, 而顧勞神 殫思, 求知天主之説, 豈不大謬? 』須果, 童子不見。士大驚, 悟知其為天人也。}

... [I] was told that there was a virtuous scholar who would like to know all about God, thinking about Him all day long. One day, as he was walking along the seashore, he met a child, who hold a bowel with cracks and walked toward the sea. The scholar asked the child, "Where will you go?" The child replied, "I like to put all the water of the sea into this bowel." The scholar laughed, "You are wrong if you want to put the entire sea into this bowel." The child answered, "Since you have known that I can't exhaust the sea by using this bowel with cracks, isn't it ridiculous for you to exhaust the knowledge about God by sparing no effort to do so?" The child then vanished in no time, and the scholar was so surprised that he was illuminated to knew that the child was an angel. ${ }^{5}$

This story was likely the most famous exemplum in the Ming and the Qing dynasties. Several known and unknown authors of this period quoted it intensively in their respective texts. ${ }^{6}$ Although Ruggieri tells a complete story in his book, the European originals of his story, the one in the Iberian Libro de los enxienplos por a.b.c. for instance, relates that virtually, St. Augustine, while writing a book on the Trinity, was admonished by a cherubic child he encountered along the seashore that the endeavor was as futile as trying to put all the ocean into a small hole in the sand one spoonful at a time. ${ }^{7}$ Famous as this "Vision of St. Augustine" may be, it is not found in any of Augustine's works, including his well-known Confessions. In addition to indicating the exact source of this exemplum, one should know that, in the context of Ruggieri's catechism, it is enlisted to demonstrate that God is totally beyond human knowledge. The child's analogy is nothing short of an apocalypse for Augustine the "shengren 聖人," a term for "saint" appropriated in the revised, 1630 version of the Tianzhu shilu (Luo 1966, 2:769-770), in that it reveals to him human smallness and divine grandeur. This story, generally attributed to Augustine of course, not only has the intrinsic interest of all good tales and the concreteness of all analogies, but it also functions as authorities (St. Augustine as a "shengren," for whom Confucians show great respect), not merely because it quotes the "life" of an authoritative figure, but also because it itself is truth and thus authority incarnate (cf. Gregg 1997, pp. 11-16).

5 My translation. For the Chinese text of the story, see Luo 2002, 1:14-15. For the nature of Tianzhu shilu, see Front 2019, pp. 201-25.

6 So far as I know, the anonymous Chinese authors of Xingmi pian醒迷篇 ( 2002), Tianzhu shengiiao koduo天主聖教口鐸 ( 2013), Lun fuli xiushi論輔理修士 ( 2013), and Shanyi shengxue三一聖學 ( 2009) all quote the "Vision of St. Augustine" in their respective titles. See Zhong et al. 2009, 9:268-269; 9:268-269; Zhong et al. 2009, 3:428-430; Zhong et al. 2013, $20: 130$. For known authors' citations, see Li 2009; Zhou 2013, 27:148.

7 See Sánchez 1992, p. 277. Ricci, in his Tianzhu shiyi天主實義, offers the first “correct" version as paraphrased in the text. See Li 1965, 1:395. 


\section{Ciceronian Rhetoric and Its Representation in Ming China}

When one considers the settings and origins of exempla or the European cautionary stories as a whole, one finds that they can be roughly divided into two categories, as suggested earlier: classical and Christian types. The supposedly biographical tales in what St. Jerome (340-420) calls Vitæ patrum (third century) and in Jacobus de Voragine's (1230-1298) Legenda aurea (c. 1260) generally have been thought of as typical sources of Christian type of exemplum..$^{8}$ As for the classical species, fable and anecdotes are the most prominent typologies (Kaufmann 1995, pp. 66-93; Carter 1928, pp. 7-8). Exemplum is therefore one of the effective rhetorical devices, a literary ars that not only makes its way into China before any other literary genres from the West but is no doubt a subject also related to the problems of language.

It requires little imagination to see that once the Jesuits recognized that there was no standardized Chinese in its spoken form (or even in its colloquial, written form), they were confronted with the necessity of adjusting their concept of European rhetoric. In the period when Ruggieri and Ricci sailed eastbound, rhetoric had already become part of Jesuit curricula (Ganss 1996, p. 296; Fitzpatrick 1993, pp. 208-16)..$^{9}$ It was, however, by no means what is known as the sacred oratory of the Renaissance, which features expository and exegetical allegiance to Roman orthodoxy (McGinness 1995, pp. 3-8). Judging from the contents of the Jesuit texts in Chinese, one may conclude that what Ricci and his Jesuit fellows had been trained to do in such Jesuit institutes as the Collegio Romano and Coimbra University falls into the category of medieval ars praedicandi. I am of this opinion because the use of exempla had been condemned harshly ever since the Council of Trent (1545-1563), and also because only in such medieval artists of preaching as Alan of Lille (d. 1202) can one find the firmest support of the use of the classical type of sermon exemplum - under the aegis of the rhetoric of exemplification. Medieval though Alan might be, he and his preaching theory were well known in the Renaissance (Walsh 1977, pp. 117-36; Wilks 1977, pp. 137-57), and they might have stimulated the formation of Jesuit sacred lectures, in all likelihood through indirect sources.

As is the case with classical rhetoric, the medieval art of preaching is indeed no more than an ars of religious oration, with greater emphasis on oral training than on writing (O'Malley 1993, pp. 94-95). This can be seen clearly by a glance at Cypriano Soarez's (1524-1593) De arte rhetorica (Soarez 1955), a textbook of rhetoric widely used in the Jesuit educational institutions of the Renaissance. ${ }^{10}$ Although Soarez wrote the book to "assist the young men to read the learned books of Aristotle (384-322fli BCE), Cicero (106-43 BC), and Quintilian (c. 35-c. $100 \mathrm{AD}$ ) wherein lies the well-springs of eloquence, "he argues that eloquence is no more than a means to the higher end of a more virtuous life on earth as preparation for a fuller existence in another, better world." To "draw greater profit from eloquence," one therefore must "carefully purify it by Christian teaching" (Soarez 1955, p. 113). The Ciceronian tasks of rhetoric, namely (1) inventio, (2) dispositio, (3) elocutio, (4) memoria, and (5) actio (pronouncio), are the major parts in the structure of De arte rhetorica.

Oration is the science of efficient and successful speech, but the Ciceronian parts of rhetoric might have to undergo an essential metamorphosis in Ming China due to the latter's different definition of its "common language." Aleni's Xixue fan has been generally conceived of as the first introduction to Ciceronian rhetoric in China, ${ }^{11}$ but this is a long-standing, serious mistake; Aleni's formulation of the five procedures actually bases itself on Alfonso Vagnone's (高一志, 1566-1640) paraphrase of them

8 For the texts where Christian type of exemplum was often made of, see Rosweyd 1864, in J.-P. Migne, ed. 1862-1864, vol 73; Waddell 1987; and Voragine 1993. It is said that it was partially for the latter collection that Ignatius of Loyola made up his mind to be a priest (Tylenda 1985, p. 12). Ignatius's dramatic decision had itself become a Christian exemplum in Alfonso Vagnone's work in Chinese before 1628 (Gao, in Zhong et al. 2002, 1:367-68). For a modern discussion on the rhetoricity of this episode in Ignatius's autobiography, see Boyle 1997, pp. 5ff.

9 For more discussions, see Grendler 1989, pp. 377-81; and Lang 1952, pp. 286-98.

10 Most of the important texts concerning the medieval art of preaching can be conveniently found in Miller et al. 1974. For an excellent survey, see Murphy 1974, pp. 269-355.

11 For a discussion on this subject, see D’Elia 1950, pp. 58-76. For Aleni's text, see Ai 1964, pp. 27-30. 
in his 1615 treatise written to describe "Western learning" (西學). ${ }^{12}$ Vagnone's paraphrase, in turn, is developed from the related passage in Soarez's vade mecum of religious rhetoric, though Soarez bases his discourse on Cicero:

\section{[此五法者] 先究事物人時之勢, 而思具所當言之道理, 以發明其美意焉。次貴乎先後布置有 序, 如帥之智者節制行伍 : 勇者置於軍之前後, 而懦者屯之於中。次以古語美言潤飾之。次 以所成議論嫻習成誦，默識心胸，終至於公堂或諸智者之前辯誦之。(Gao 1995, 1:371-372)}

[The five parts of rhetoric] begin with the study of things, events, persons, and the conditions of times before one speculates on the cause of delivering one's speech for the presentation of one's proper intention. What is important next is the deployment [of materials and arguments.] This has to be made in good order, in the way as a wise commander would do with his troop: the brave will be deployed in front and at the back of the troop, while the cowardly will be placed in the middle. And then one adorns one's speech with antique gems and beautiful diction. And then one commits to memory the finished discourse by recitation. Finally one delivers it in a public hall or disputes it with wise persons. ${ }^{13}$

The related comparison made by Soarez is of course taken from Cicero's De oratore and Quintillian's Institutio oratoria (Cicero 1996, I. xxxi. 143-147; Quintilian 1993, III. iii. 1-iv. 15; also see Cicero 1989, I. ii. 3). De oratore was a common text for rhetoric classes in the schools of the Renaissance and the Reformation as well. Removing the troop comparison from this context, Aleni elaborates on Vagonone's idea as follows:

[西人]議論之法, 大約必由五端 :一先觀物觀事, 觀人觀時勢, 而習䚇道理以相質, 所謂種 種議論之資料是也。二貴乎先後布置有序而不紊。三以古語擷華潤色。四將所成議論嫻習成 誦, 默識心胸。其人靈悟善記, 則有温養之法 ; 其人善忘難記, 則有習記之法。終至於公所 主試者之前誦説之, 或登高座與諸智者辯論焉。蓋議論本欲破人之疑而發其志, 以善處其 事, 不能通人之心, 感人之情, 無益也。故言語之輕重疾徐, 以至容貌顧眪, 舉手順目, 皆 有其法, 俾聽者之愛惡悲喜, 言下即觸, 不徒浮言散於空中而已。

As for the method of discourse, there are five steps. First, to observe things, events, persons, and the conditions of the times, and to seek the causes behind them; such are called materials for discourse. Second, to deploy [materials and arguments] in good order: first this, then that. Third, to adorn with gems from ancient writers. Fourth, to commit to memory the finished discourse. If a student is intelligent and good at memory, there is method for keeping his memory fresh. If the student is forgetful, there is the art of memory. Finally, the student appears in a public hall in front of the examiners to recite his discourse or mounts a platform for a disputation with wise and learned persons. Now the purpose of discourse is to pierce the doubts and guide the will of the listened, for it does little benefit if one is capable of handling affairs but incapable of moving the hearts and emotions of others. Hence, there is a method, too, in the stress and speed of delivery, in the facial expressions, and in the movements of the

12 For the year the chapter on Western learning was completed, see Mei 2017, p. 216n2.

13 My translation here is done partially by following Bernard Hung-kay Luk's rendition of Aleni's version, with different wording and diction, in Xixue fan. See Luk 1977, p. 70. Unfortunately, Luk is ignorant of Aleni's borrowing from Vagnone, nor is he aware of Vagnone's borrowing from Soarez. He thus comes to the misleading conclusion that the Ciceronian parts of rhetorical formation "are quite obviously derived from Cicero's De oratore." I agree that Soarez's source is Cicero, De Oratore, 1.31.142-143, but it is clear that Vagnone's source is De Arte rhetorica. An obvious evidence of Vagnone's borrowing from Soarez lies in their shared emphasis on the simile of the commander and his troop. Soarez's original in this context, to quote Flynn's translation, reads, "The calibre of a distinguished commander is not better discerned from his selection of the brave and the spirited soldiers for war, than from posting an army for battle" (Soarez in Flynn 1955, p. 209). Elsewhere, Soarez uses the same figure of idea once more, although not so relevant to my argument: "The army that has a wise commander is governed more satisfactorily in all respects than one ordered by some rash and stupid person" (Soarez in Flynn 1955, p. 240). 
hands and eyes, of the speakers, so that the words will touch the listeners' loves and hates, sorrows and joys and do not merely disperse in the air. ${ }^{14}$

Despite Vagnone's use of such words as "dispute" and "recitation," he paradoxically designates the result of these steps as "the essay of the Far West" (太西之文), rather than as its "speech" or "oration." Such designation, in other words, has laid bare Vagnone's intention to accommodate European rhetoric to Chinese literary culture, which generally bases itself on writing rather than on speaking. I believe that what had motivated Vagnone to make the designation must have been greatly influenced by his understanding of what the "language" commonly shared by the Ming Chinese was: it is the so-called wenyanwen 文言文 or literary Chinese. Aleni's elaboration upon Vagnone in his Xixue fan reflects even more the same understanding. He identifies leduolijia 勒鐸里加 (rhetorica) as the "science of literature" (文㙯之學) and specifies its contents as “proverbial sayings of the ancient sages" (古賢名訓), “books on history of different nations" (各國史書), “poetry and prose of different kinds" (各種詩文), and "essays and argumentative articles written by individuals" (自撰文章、議論) (Ai 1964, p. 28). Obviously, here, the study of oration has been turned to become that of the written, literary language. To put it one more step further and, therefore, more precisely, through the joint efforts of the late-Ming Jesuits, the late-Qing Protestant missionaries like Joseph Edkins, and some Ming-Qing Chinese scholars such as Yang Tingyun (楊廷筠, 1562-1627) and Wei Yuan (魏源, 1794-1857), the “wen" in Vagnone's translation would later undergo an essential transformation from rhetoric into a Sino-European "wenxue文學" or literature, as I have indicated elsewhere (Li 2017, pp. 29-34). Such a transliterated transmutation of rhetorica into leduolijia, one should also note, had already been foreshadowed by an observation Ricci made some twenty years earlier. Ricci wrote in his Storia dell'Introduzione del Cristianesimo in Cina that all Chinese "rettorica et eloquentia" were to be found "in their writings rather than in the spoken word, in which they resemble Isocrates, who had a reputation among the Greeks for the eloquence of his writings." 15

\section{European and Chinese Rhetoric Compared}

Chinese, in fact, is by no means lacking in "rettorica" or "rhetorica," albeit of a different nature. ${ }^{16}$ Texts which teach debate or verbal discourse have been found in works spanning from Xunzi 荀子 through Hanfeizi 韓非子 to The Literary Mind and the Carving of the Dragon. ${ }^{17}$ Authors of especially pre-Qin times (pre-221 BCE), however, were born in different kingdoms and thus might speak different languages. What they talked about in their individual works on "rhetoric," i.e., bian 辯, shuo 説, yi 議, dui 對, or lun 論, might thus vary to a certain degree, especially in oral presentation (Lu 1998, pp. 468-93). In addition, in this period, the Chinese idea of persuasion might lack "the connotation of artistic composition or style, which 'rhetoric' often carries in the West," and it henceforth, is replete with political imports. By the standards of Aristotle's On Rhetoric or Alan's Art of Preaching, which bases its discussion on an essentially common spoken language, texts in neither Xunzhi nor Hanfeizhi can thus be qualified as "rhetorical." No text on "public speech" was given and thus, one more observation calls for mention: "Neither Confucius nor other Chinese thinkers held a very high opinion of the intelligence of the general public; what they have to say about speech, persuasion, and other aspects of rhetoric is addressed to rulers or to their own philosophical students and does not consider techniques of addressing a mass audience." (Kennedy 1998, p. 143) This specific feature of "ancient Chinese rhetoric" is so discrepant from that of the West that no citation or mention of other texts than Hanfeizi

14 Luk's translation with proper additions made by me. See Luk 1977, pp. 70-71. For Aleni's text, see Ai 1964, 1:28-30.

15 D'Elia 1942, 1:37. For the English translation, I quote from Gallagher 1942, p. 28.

16 As I will suggest in what follows, it has been a mistake to take xiuqi xue 修辭學as an equivalent to "rhetoric;" I prefer yantan zhishu言談之術 to it, though it is still different from Western idea of rhetoric.

17 See Xunzi 1979, “Feixiang 非相," pp. 73-91; Hanfeizi 1964, “The Difficulties of Persuasion” (“Shuonan 説難”), pp. 73-79; and Liu Xie 劉妿思, “Lunshuo 論説” and “Yidui 議對," in Liu 1985, pp. 126-33, 169-75. For a historical survey in this respect, see Song and Huang 1991, and Yuan and Zong 1990, pp. 9ff; Oliver 1971, pp. 84-257; and Garrett 1993, pp. 105-15. 
and Xunzhi need be made hereupon. Actually, the respect for oral delivery become even worse since the civil service examination system (kejia科甲) had dominated the academia of the Han dynasty; writing rather than speaking was the only way to academic fame and political as well as social success, as I have intimated earlier in this paper. It therefore made no sense at all for Ricci and his Jesuit brothers to accord the same weight to rhetoric in China as they did in the West. Furthermore, Ricci was quite conscious that not even the written colloquial Chinese was highly respected in Ming society (Ricci 1942, vol. 1, p. 37).

The idea of rhetoric as "wen," or "essay," embodies to the ultimate degree in the Notitia lingux sinicæ by the Qing Jesuit Joseph de Prémare (1666-1736). The second part of this book discusses the Chinese literary language by using rhetorical terminologies from both Cicero and Aristotle. In the book, Prémare enlists rhetorical devices such as antithesi, reptione, gradatione, confutatione (interogrationisbus), descriptione, comparationis, metaphora, fabula (yu-yen 寓言), and exemplum (pi-yu 譬喻) to illustrate characteristics of Chinese literature. He might be motivated by the Chinese literatus Liu Ning 劉凝 (1620-c. 1715) to compose this part (Li 2015, pp. 123-28; Mungello 1979, pp. 8-9, 77-79; Lundbæk 1991, pp. 141-47), but his "figuris orationis," interestingly, place more emphasis on the particulars of Chinese written language than on its spoken counterpart. (Prémare 1831, pp. 204-48) For Notitia linguæ sinicx, rhetoric is thus not an ars of effective speaking but, instead, it is that of beautiful writing. In this Qing work of Prémare's, the echoes of Vagnone and Aeni's idea is clearly and strongly heard.

Given the Ming "rhetorical" circumstances, all the Jesuits could do to put the Alanian art of preaching into practice, besides verbal stories told occasionally, would have to depend greatly on written exempla or on exempla re-contextualized in, oxymoronically, written preaching, as Ricci has done in his Jiren shipian 畸人十篇 (Ten Chapters from a Strange Person, 1608; Li 2005). Trigault and Vagnone provided the first collections of classical, written exempla in Chinese in this period, ${ }^{18}$ while Ricci and Aleni verbalized their tales in their written texts in different forms. They were Renaissance raconteurs fairly versed in the medieval art of story-telling, certainly in literary Chinese.

\section{Exemplum and the Thematic Sermon}

One may, of course, ask at this stage of my paper: Regardless of its Christian type, why does the medieval art of preaching also place stress on the classical, pagan type of exemplum? I have indicated previously that the Middle Ages were the climax of Christianizing brief stories from Greco-Roman lore. Most of the works at this period were done by the Dominicans and the Franciscans (Hinnebusch 1951, pp. 279-31; Bataillon 1985, pp. 191-205; Crane 1983, pp. 49-78), and their stories turned out to be direct or indirect sources of the short narratives found in the Ming Jesuits. This notwithstanding, one still has to return to Alan for a theoretical account for medieval interest in classical exempla. In his Art of Preaching, Alan gives the first definition of preaching in the history of the church; in it, the idea of authority is greatly accentuated. According to Alan, an "authority" is a quotation that authorizes an assertion a speaker or a writer makes, functioning almost as a proof text (Alan of Lille 1981, pp. 16-22). One finds that two types of preaching in the medieval pulpit were inspired specifically by Alan's emphasis on authorities as the fountainhead of preaching: the monastic sermon and the thematic one. Alan was himself a Cistercian, and his Cistercian peers such as St. Bernard of Clairvaux (c. 1090-1153) and Odo of Cheriton (c. 1185-c. 1247) were most enthusiastic practitioners of this or a similar theory by developing their sermons from biblical texts, the most authoritative "authorities" (McGuire 1983, pp. 211-67; Matarasso 1993, pp. 295-304). Side by side with this idea of authority arose the monastic form of preaching that was no more than a shapeless verse-by-verse comment on a passage from the Bible (Matarasso 1993, pp. 65-82). The Franciscans and the Dominicans were traveling mendicants preaching in and around the cities. Before they became prominent in the 1220s, they had prepared themselves for their preaching by studying at the new universities then being founded (Lesnick

18 See Kaufmann 1995, 4: 305-343; Gao 2009, vol. 4, pp. 3393-3401; cf. Li and Meynard 2014, pp. 182-341. 
1989, pp. 94-95). With their scholastic background, they developed the first real homiletical form, known mostly as the thematic sermon; this form, I would argue, must have contributed greatly to the morphological formation of such Jesuit texts as Pantoja's Qike 七克 (The Conquest of the Seven Deadly Sins, 1614), Ricci's Jiren shipian, and Martino Martini's (衛匡國, 1614-1661) Qiouyou pian 述友篇 (A Treatise on Friendship) (Li 1964, vol. 2, pp. 689-1126; vol. 1, pp. 93-282; Wei 1984, in Wu, 1:1-88).

Compared with the monastic sermon, the thematic one has more to do with the formal use of classical and Christian exempla. It was constructed on the basis of a theme, an authority in pulpit actuality. The theme would then be divided into a number of parts, and these were, in turn, subdivided into a number of sub-points. Alan's idea of authority became involved generally at this juncture of shaping the subdivision, for the affirmations made in each part of it were expected to be supported, or even "dilated," by the quotation of authorities, including illustrations by exempla (D'Avray 1995, pp. 263-73). Here, the idea of the authority had undergone a transmutation from the theme of a sermon to its illustration. What, then, constituted the medieval corpus of "authorities as illustrations"? In the words of Alan, first and foremost, "books of Holy Writ," then patristic writings, and finally "sayings of the pagan writers" (Alan of Lille 1981, pp. 20-22). In the mouth of the Dominicans and the Franciscans, Alan's specification for the last category would be generalized as "classical exempla," and the others would be the Christian type of exemplum.

To facilitate the composition of a sermon, the thematic one in particular, there appeared in the high and late Middle Ages several types of preaching aids or pastoral manuals, mostly in Latin. ${ }^{19}$ Among them, two call for special attention: the collections of model sermons on virtues and vices and the collections of exempla arranged in alphabetical order by topics. ${ }^{20}$ The former provided the Ming Jesuits with a base to be mined for form and material from which to construct their "written preaching" in literary Chinese on the same subjects. The latter, having been medieval "cyclopedias of illustration," supplied them with an inexhaustible treasury of Christian and classical tales to be enlisted in support of their themes, or the points they wished to make, in their "written preaching," or simply, "books on Christian topoi." To these two collections, one must add the collections of chreiai reworked on classical biographies or textbooks of basic rhetoric, when one considers the Jesuit use of anecdote. ${ }^{21} \mathrm{I}$, together with Thierry Meynard, have written a book in English to illustrate what a chreia is, especially those in Chinese. In addition, I have also devoted one book to pinpointing part of my major concerns in this paper (Li 2005). To make it short, my arguments have been drawn partially from a linguistic comparison between the Jesuit tales in Chinese and their European counterparts found in the two types of preaching aids mentioned above.

\section{Coda}

Since both the classical and the Christian species of medieval exemplum is a form of sermon illustration, they certainly owe their genesis to classical rhetorical theory concerning examples; this fact accounts for my earlier reference to Aristotle's On Rhetoric. But a few more remarks in relation to the Jesuit use of a medieval preaching style discussed above need to be made before I move to the close of this paper. It is true that Aristotle's work on rhetoric had failed to exercise a direct influence on medieval rhetoric until the thirteenth century, but one can hardly disavow its role in the formation of the Alanian art of preaching. As is well known, the medieval art of pulpit oratory was greatly indebted to Book Four of St Augustine's (354-430) Doctrina christiana (Mountford 1991, pp. 27-53). St. Augustine's meticulous study on this subject, however, bases itself on Ciceronian rhetoric. Despite Cicero's theoretical renovations in rhetorical specifics such as speech stylistics and the five tasks of the rhetor, the major portion of his rhetorical thinking was derived from Aristotle (Cicero 1996, I. xxxll.

19 There were, of course, exceptions in the vernacular. For examples in this regard, see Crane 1983, pp. cii-cxvi.

20 For a discussion of the collections of model sermons, see Bataillon 1980, pp. 19ff. For discussions of the collections of "alphabet of tales," see Pfander 1934, pp. 19-29. Cf. Nolcken 1981, pp. 271-84.

21 For an introduction to such collections and anthologies, see Kindstrand 1986, pp. 226-42; and Kloppenborg 1987, pp. 306-15. 
144-145; Kennedy 1994, pp. 141ff.). For this reason, although the Greek rhetorician was absent from most of the medieval scene, he remained clearly felt through the Ciceronian school of rhetoric, which was then authoritative (Caplan 1933, pp. 73-96). Also for this reason, it takes little imagination to see that the Jesuits of the Ming and the Qing dynasty may have owed their employment of exempla to Aristotle's theory of logical proof as implied in the medieval art of preaching, not to mention their overt familiarity with it through Soarez's De arte rhetorica.

I have indicated at the outset of this paper that traditional scholars in the field of Christianity in China generally held that the Chinese converts in the Ming could be persuaded only by the Jesuit presentation of European material culture. What led to such a conclusion, to the best of my knowledge, might have been an ingrained sense of cultural superiority on the part of the Chinese. Before the middle of the Qing dynasty, Chinese official-scholars in the mainstream could hardly subscribe to the view that beyond China one could find a country of equal cultural excellence, especially in regard to literary achievement. However, the evangelical truth may have been the other way around, in that, as I have also pointed out earlier, religion is spiritual in essence and its proselytism can scarcely be dominated by material contributions alone. Sallie McFague forcefully indicates in her study of Jesus's parables that "Christian belief must always be a process of coming to belief-like a story" (McFague 1975, p. 3). She implies, in this observation, that sermon stories like the parables of Jesus, more often than not, may be the primary mover of one's spiritual formation. If McFague's theory is plausible, even if only in part, then the importance of the classical and Christian types of Jesuit exemplum, a religious sub-genre appropriated due to the Jesuit restoration of the medieval art of preaching, should not be underestimated. In this light, if what I have said in my books concerned is able to break down the long-standing, traditional prejudices concerning Chinese conversion in the late Ming and the early Qing dynasty and concerning the Jesuit contributions to Chinese culture at this period, that success may be credited to Aristotle and Cicero, the fountainhead, though indirect, of the medieval ars praedicandi.

Funding: This research received no external funding.

Conflicts of Interest: The author declares no conflict of interest.

\section{References}

Ahn, Jaewon. 2017. On Xiguo Jifa (『西國記法』) of Matteo Ricci (1552-1610). Journal of Greco-Roman Studies 56: 99-121.

Ai, Rulue, (Julius Aleni). 1964. Xixue Fan. Edited by Zhizhao Li. Tienxue chuhan. Taipei: Ricci Institute.

Ai, Yueshe, (Joseph Edkins). 2006. Xila wei Xiguo wenxue zhi zhu. In Liuhe Congtan, Fu Jieti, Suoyin. Edited by Shen Guowei. Shanghai: Shanghai cishu chupanshe.

Alan of Lille. 1981. The Art of Preaching. Translated by Gillian R. Evans. Kalamazoo: Cistercian Publication.

Anonymous. 2002. Xingmi pian. In Yeshuhui Luoma Dan'anguan Ming Qing Tianzhujiao Wenxian. Edited by Mingdan Zhong (Nicolas Standaert) and Dingke Du. Taipei: Ricci Institute, vol. 12, pp. 239-388.

Anonymous. 2009. Shanyi Shengxue. In Faguo Guojia Tushuguan Ming Qing Tianzhujiao Wenxian. Edited by Mingdan Zhong, Dingke Du and Xi Mon. Taipei: Ricci Institute, vol. 26, pp. 401-628.

Anonymous. 2013. Lun fuli xiushi. In Xuejiahui Chanshulou Ming Qing Tianzhujiao Wenxian Xuibian. Edited by Mingdan Zhong, Dingke Du and Renfang Wang. Taipei: Ricci Institute, vol. 23, pp. 469-582.

Anonymous. 2013. Tianzhu shenjiao koduo. In Xuejiahui Chanshulou Ming Qing Tianzhujiao Wenxian Xuibian. Edited by Mingdan Zhong, Dingke Du and Renfang Wang. Taipei: Ricci Institute, vol. 34, pp. 1-325.

Bataillon, Louis-Jacques. 1980. Approaches to the Study of Medieval Sermons. Leeds Studies in English 11: 19-30.

Bataillon, Louis-Jacques. 1985. Simitudines et exempla dans les sermons du XIIIe siècle. In The Bible in the Medieval World: Essays in Memory of Beryl Smalley. Edited by Katherine Walsh and Diana Wood. Oxford: Published for the Ecclesiastical History Society by Basil Blackwell, pp. 191-205.

Timothy Billings, trans. 2009, [Matteo Ricci] On Friendship: One Hundred Maxims for a Chinese Prince. New York: Columbia University Press.

Boyle, Marjorie O'Rourke. 1997. Loyola's Acts: The Rhetoric of the Self. Berkeley and Los Angeles: University of California Press. 
Caplan, Harry. 1933. Classical Rhetoric and the Medieval Theory of Preaching. Classical Philology 28: 73-96. [CrossRef] Carter, Minnie Luella. 1928. Studies in the Scala celi of Johannes Gobii Junior. Ph.D. dissertation, University of Chicago, Chicago, IL, USA.

Chen, Ding, comp. 1991. Tonglin liezhuan. In Mingdai zhuanji congkan. Edited by Junfu Zhou. Taipei: Mingwen, vol. 24.

Chu, Ping-yi. 1996. Shenti, linghuan yu Tianzhu: Mingmo Qingchu Xixue zhong de renti shengli zhishi. Xinshixue 7: 47-97.

Cicero. 1989. Ad Herennium. In Cicero I. Cambridge: Harvard University Press.

Cicero. 1996. De Oratore. In Cicero III. Translated by Edwad Wlliam Sutton, and Harris Rackham. Cambridge: Harvard University Press.

Crane, Thomas Frederick. 1983. Medieval Sermon-Books and Stories. Proceedings of the America Philosophical Society 21: 49-78.

D'Avray, D. L. 1995. Philosophy in Preaching: The Case of a Franciscan Based in Thirteenth-Century Florence (Servasanto da Faenza). In Literature and Religion in the Late Middle Ages: Philological Studies in Honor of Siegfried Wenzel. Edited by Richard G. Newhauser and John A. Alford. Binghamton: Center for Medieval and Renaissance Texts and Studies, State University of New York at Binghamton, pp. 263-73.

D’Elia, Pasquale. 1942. Fonti Ricciane. 3 vols. Rome: La Libreria dello Stato.

D’Elia, Pasquale. 1950. Le Generalita sulle Scienze Occidentali di Giulio Aleni. Rivista degli Studi Orientali 25: 58-76.

Engelfriet, Peter M. 1998. Euclid in China: The Genesis of the First Chinese Translation of Euclid's Elements, Books I-VI (Jihe yuanben, Beijing, 1607) and Its Reception up to 1723. Leiden: Brill.

Fan, Hongye. 1992. Yesuhuishi yu Zhongguo kexue. Beijing: Zhongguo renming daxue chubanshe.

Fitzpatrick, Edward A., ed. 1993. St. Ignatius and the Ratio Studiorum. New York: McGraw-Hill.

Front, Philos. 2019. The Tianzhu Shilu. Revisited: China's First Window into Western Scholasticism. China 14: 201-25.

Louis Joel. S.J. Gallagher, trans. 1942, China in the Sixteenth Century: The Journals of Matthew Ricci: 1583-1610. New York: Random House.

George E. Ganss, trans. 1996, Constitutions of the Society of Jesus. Saint Louis: The Institute of Jesuit Sources.

Gao, Yizhi, (Alfonso Vagnone). 1995. Tongyou jaioyu. In Xujiahui changshulou Ming Qing Tianzhujiao wenxian. Edited by Mingda Zhong, Dingke Du and Xi Mon. Taipei: Fangji Chupanshe, vol. 5.

Gao, Yizhi. 2009. Lixue guyan. Edited by Mingda Zhong, Dingke Du and Xi Mon. Taipei: Ricci Institute, vol. 26, pp. 1-66.

Garrett, Mary M. 1993. Classical Chinese Conceptions of Argumentations and Persuasion. Argument and Advocacy 29: 105-15. [CrossRef]

Gernet, Jacques. 1986. China and the Christian Impact. Translated by Janet Lloyd. Cambridge: Cambridge University Press.

Gregg, Joan Young. 1997. Devils, Women, and Jews: Reflections of the Other in Medieval Sermon Stories. Albany: State University of New York Press.

Grendler, Paul F. 1989. Schooling in Renaissance Italy: Literacy and Learning, 1300-1600. Baltimore: Johns Hopkins University Press.

Han, Qi. 2019. Kangxi huangdi, Yeshuhuisi, Kexue Chuanbo. Beijing: Zhongguo da baikequanshu chubanshe.

Hanfeizi. 1964. The Difficulties of Persuasion (Shuonan). In Basic Writings of Mo Tzu, Hsun Tzu, and Han Fei Tzu. Translated by Burton Watson. New York: Columbia University Press, pp. 73-79.

Hinnebusch, William A. 1951. The Early English Friars Preachers. Rome: Institutum Historicum FF. Praedicatorum. Jin, Nige. 2009. Kuangyi . In Faguo guojia tushuguan Ming Qing Tianzhujiao wenxian. Edited by Mingdan Zhong, Dingke Du and Xi Mon. Taipei: Ricci Institute, vol. 4, pp. 305-43.

Kaufmann, Hanna Wanda. 1995. The Exemplum: Its Morphology, Function, Evolution and Transmission. Ph.D. dissertation, University of Texas, Austin, TX, USA.

George Kennedy, trans. 1991, Aristotle. In On Rhetoric. Oxford: Oxford University Press.

Kennedy, George A. 1994. A New History of Classical Rhetoric. Princeton: Princeton University Press.

Kennedy, George A. 1998. Comparative Rhetoric: An Historical and Cross-Cultural Introduction. Oxford: Oxford University Press.

Kindstrand, Jan Fredrik. 1986. Diogenes Laertius and the Chreia Tradition. Elenchos 71-72: 226-42.

Kloppenborg, John S. 1987. The Formation of Q: Trajectories in Ancient Wisdom Collections. Philadelphia: Fortress Press. 
Lang, Robert T. 1952. The Teaching of Rhetoric in French Jesuit Colleges, 1556-1762. Speech Monographs 19: $286-98$. [CrossRef]

Lesnick, Daniel R. 1989. Preaching in Medieval Florence: The Social World of Franciscan and Dominican Spirituality. Athens: University of Georgia Press.

Li, Madou. 1964. Xiguo jifa. In Tianzhujiao Dongchuan Wenxian. Edited by Xiangxiang Wu. Taipei: Xuesheng, pp. 1-70.

Li, Madou. 1965. Tianzhu shiyi. In Tianxue Chuhan. Edited by Zhizao Li. Taipei: Xuesheng, vol. 1, pp. 351-636.

Li, Sher-shiueh. 2005. Zhongguo wan-Ming yu Ouzhou wenxue-Mingmo Yeshuhui zhengdao gushi kaoquan. Taipei: Liangjing.

Li, Jiugong. 2009. Lixiu Yijian. Faguo Guojia Tushuguan Ming Qing Tianzhujiao wenxian. Edited by Mingdan Zhong, Dinke Du and Xi Mon. Taipei: Ricci Institute, vol. 7, pp. 67-179.

Li, Zhen. 2015. Shilun Ming Qing zhi ji lai Hua Yesuhuishi yu Rujia Jidutu zhi xueshu jiaowang: yi Ma Ruoshe yu Liu Ning wei zhongxin. Beijing xingzhen xueyuan xuebao 2: 123-28.

Li, Sher-Shiueh. 2017. The Multiple Beginnings of Modern Chinese 'Literature. In A New Literary History of Modern China. Edited by David Der-wei Wang. Cambridge: Harvard University Press, pp. 29-34.

Li, Sher-shiueh, and Kid Lam, eds. 2014. Wan-Ming Tianzhujiao fanyi wenxue jianzhu. Taipei: Institute of Chinese Literature and Philosophy, Academia Sinica, vol. 4.

Li, Sher-shiueh, and Thierry Meynard. 2014. Jesuit Chreia in Late Ming China: Two Studies with an Annotated Translation of Alfonso Vagnone's "Illustrations of the Grand Dao". Bern: Peter Lang.

Liu, Xie. 1985. Lunshuo and Yidui. In Liu Xie. Wenxin diaolong [jiaozheng] 文心雕龍[校證]. Annotated by Liqi Wang. Taipei: Mingwen.

Liu, Dachun, ed. 2018. Xixue Dongjian. Beijing: Zhongguo Remin Daxue Chubanshe.

Lu, Xing. 1998. Rhetoric in Ancient China, Fifth to Third Century B.C.E: A Comparison with Classical Greek Rhetoric. Columbia: University of Southern Carolina Press.

Luk, Bernard Hung-kay. 1977. Thus the Twain Did Meet? The Two Worlds of Giulio Aleni. Ph.D. dissertation, Indiana University, Bloomington, IN, USA.

Lundbæk, Knud. 1991. Joseph De Prémare, 1666-1736, S.J.: Chinese Philology and Figurism. Aarhus: Aarhus University Press.

Luo, Mingjian. 1966. Tianzhu Shengjiao Shilu. In Tianzhujia Dongchuan Wenxien Xubian. Edited by Xiangxiang Wu. Taipei: Xuesheng, vol. 3, pp. 755-838.

Luo, Mingiian. 2002. Tianzhu Shengjiao Shilu. In Yesuhui Luoma Dang'an Guan Ming Qing Tianhujiao wenxian. Edited by Mingdan Zhong and Dinke Du. Taipei: Ricci Institute, vol. 12, pp. 1-85.

Matarasso, Pauline, ed. 1993. The Cistercian World: Monastic Writings of the Twelfth Century. Harmondsworth: Penguin. McFague, Sallie. 1975. Speaking in Parables: A Study in Metaphor and Theology. Philadelphia: Fortress Press.

McGinness, Frederick J. 1995. Right Thinking and Sacred Oratory in Counter-Reformation Rome. Princeton: Princeton University Press.

McGuire, Brian Patrick. 1983. The Cistercians and the Rise of the Exemplum in Early Thirteenth Century France: A Reevaluation of Paris BN Ms lat. 1592. Classica et Mediaevalia 34: 211-67.

Mei, Qianli, (Thierry Meynard). 2017. Tongyuo jiaoyu jinzhu. Beijing: Commercial Press.

Miller, Joseph M., Michael W. Prossel, and Thomas W. Benson, eds. 1974. Readings in Medieval Rhetoric. Bloomington: Indiana University Press.

Mountford, Roxanne Denise. 1991. The Feminization of the Ars Praedicandi. Ph.D. dissertation, Ohio State University, Columbus, $\mathrm{OH}$, USA.

Mungello, David Emil. 1979. Silencing of Jesuit Figurist Prémare. Lanham: Lexington Books.

Murphy, James J. 1974. Rhetoric in the Middle Ages: A History of Rhetorical Theory from Saint Augustine to the Renaissance. Berkeley and Los Angeles: University of California Press.

Nolcken, Christina von. 1981. Some Alphabetical Compendia and How Preachers Used Them in Fourteenth-Century England. Viator Medieval and Renaissance Studies 12: 271-84. [CrossRef]

O'Malley, John W. 1993. The First Jesuits. Cambridge: Harvard University Press.

Oliver, Robert T. 1971. Communication and Culture in Ancient India and China. Syracuse: Syracuse University Press.

Pfander, Homer G. 1934. The Medieval Friars and Some Alphabetical Reference-Books for Sermons. Medium Ævvum 3: 10-19. [CrossRef]

Prémare, Joseph Henri. 1831. Notitia Linguæ Sinicæ. Malaccæ: Collegii Anglo-Sinici. 
Quintilian. 1993. Insttutio oratoria. Translated by Harold Edgeworth Butter. Cambridge: Harvard University Press, III. iii. 1-iv. 15.

Redaelli, Margherita. 2007. Il mappamondo con la Cina al Centro: Fonti Antiche e Mediazione Culturale Nell'poera di Matteo Ricci S.J.. Pisa: Edizioni ETS.

Ricci, Matteo, S.I. 1942. Storia dell'Introduzione del Cristianesimo in Cina. In Fonti Ricciane. Edited by Pasquale M. D’Elia S.I. Rome: La Libreria dello Stato, vol. 3.

Rosweyd, Herbert. 1864. Vitae patrum sive historiæ eremiticæ libri decem. In Patrologiæ Lainæ. Edited by J.-P. Migne. Paris: Excudebat Migne 1844-1855, 1862-1864, vol. 73.

Sánchez, Clemente. 1992. The Book of Tales by A.B.C. (Libro de los exienplos por a.b.c). Translated by John Esten Keller, Louis Clark Keating, and Eric M. Furr. New York: Peter Lang.

Soarez, Cypriano. 1955. De Arte Rhetorica. In Lawrence J. Flynn, S.J. The De Arte Rhetorica (1568) by Cyprian Soarez, S.J.: A Translation with Introduction and Notes. Ph.D. dissertation, University of Florida, Gainesville, FL, USA.

Song, Silian, and Yuwen Huang. 1991. Zhongguo Gudai Yanshuoshi. Jilin: Dongbei Shifan Daxue.

Standaert, ed. 2001. The Handbook of Christianity in China. Volume One: 635-1800. Leiden: Brill.

Joseph N. Tylenda, trans. 1985, A Pilgrim's Journey: The Autobiography of Ignatius of Loyola. Collegeville: Liturgical Press.

Voragine, Jacobus. 1993. The Golden Legend: Readings on the Saints. Translated by William Granger Ryan. 2 vols. Princeton: Princeton University Press.

Waddell, Helen. 1987. The Desert Fathers. London: Constable.

Walsh, Patrick Gerald. 1977. Alan of Lille as a Renaissance Figure. In Renaissance and Renewal in Christian History. Edited by Derek Baker. Cambridge: Cambridge University Press, pp. 117-36.

Wei, Kuanguo, (Martino Martini). 1984. Qiouyou pian. In Tianzhujiao Dongchuan Wenxian Sanbian. Edited by Xiangxiang Wu. Taipei: Xuesheng, vol. 1, pp. 1-88.

Wilks, Michael. 1977. Alan of Lille and the New Man. In Renaissance and Renewal in Christian History. Edited by Derek Baker. Cambridge: Cambridge University Press, pp. 137-57.

Xie, Zaozhe. 1959. Wu Zazhu, Juan 4. Beijing: Zhonghua.

Xunzi. 1979. “Feixiang”. In Xunzi, Xunzi [jijie]. Annotated by Disheng Li. Taipei: Xuesheng, pp. 73-91.

Yuan, Huan, and Tinghu Zong, eds. 1990. Hanyu xiucixueshi. Hefei: Anhui Jiaoyu.

Zhong, Mimgdan, Dingke Du, and Xi Mon, eds. 2002. Jesuhui Luoma dan'angun Ming-Qing Tianzhujiao wenxian. vol. 12 .

Zhong, Mingdan, Dingke Du, and Xi Mon, eds. 2009. Faguuo guojia toshuguan Ming-Qing Tianzhujiao wen xian. Taipei: Ricci Institute, vol. 26.

Zhong, Mingdan, Dingke Du, and Renhuang Wang, eds. 2013. Xujihui changshu lou Ming-Qing Tianzhujiao wenxian xubian. Taipei: Ricci Institute, vol. 34.

Zhou, Zhi. 2013. Shengjaio ge zhanli duoyin. Vol 1. In Xujihui changshulou Ming Qing Tianzhujiao wenxian xubian. Edited by Mingdan Zhong, Dingke Du and Renhuang Wang. Taipei: Ricci Institute, vol. 27, pp. 1-210.

Zhu, Xi, anno. 1997. Confucius, Lunyu. In Shishu Jizhu. Taipei: Shijie.

Zou, Weilian. 2001. Pixie guanjian lu. In Mingmo Qinchu Tianzhujiao Shi wenxian congbian. Edited by Mifang Zhou. Beijing: Beijing Tushuguan Chubanshe, vol. 3.

Zürcher, Erik, ed. 1991. Bibliography of the Jesuit Mission in China (ca. 1580-ca. 1680). Leiden: Center of Non-Western Studies, Leiden University, pp. 101-24.

Zürcher, Erik. 1996. Renaissance rhetoric in Late Ming China: Alfonso Vagnoni's Introduction to His Science of Comparison. In Western Humanistic Culture Presented to China by Jesuit Missionaries (XVII-XVIII Centuries). Edited by Federico Masini. Rome: Institum Historicum S.I, pp. 331-60.

(C) 2019 by the author. Licensee MDPI, Basel, Switzerland. This article is an open access article distributed under the terms and conditions of the Creative Commons Attribution (CC BY) license (http://creativecommons.org/licenses/by/4.0/). 